\title{
APPLICATION OF CONTEMPORARY EQUATED YIELD AND DCF EXPLICIT GROWTH METHODS IN THE VALUATION OF OVER-RENTED PROPERTIES IN A RECESSIONARY PERIOD: A CASE STUDY OF NIGERIA
}

\author{
Vincent Uwaifiokun Aihie, M.Sc. \\ University of Benin \\ e-mail:Vincent.aihie@uniben.edu
}

\begin{abstract}
Valuations have always been time specific and, if properly undertaken, are supposed to give a true reflection of property market conditions at any given point in time. In periods of economic decline, when properties are leased or tend to exchange hands at rents or prices lower than their true market value, a need to capture the explicit growth rate associated with an instability in the property market arises. With the Nigerian economy currently facing its worst recession in years, the onus is on valuers to adopt contemporary methods of valuation which seek to mirror the true situation of the property market at any point in time; something which, hitherto, conventional methods of valuations have failed to do. This paper therefore takes a pilot survey of the types of investment valuation models currently adopted by valuers when carrying out valuations of reversionary properties in a recession. The study seeks to highlight the knowledge gap of valuers, both in practice and in the academia, concerning the use of the Equated yield and DCF explicit growth method of valuation, and hence enlighten them and the general public on its use as a more appropriate method of valuing properties during a downturn.
\end{abstract}

Key words: equated yield, discounted cash flow, explicit growth method, over-rented properties, reversionary valuation.

\section{JEL Classification: $D 46$.}

Citation: Aihie V.U., 2018, Application of the Contemporary Equated Yield and DCF Explicit Growth Methods in the Valuation of Over-Rented Properties in a Recessionary Period: a Case Study of Nigeria, Real Estate Management and Valuation, vol. 26, no. 3, pp. 35-50.

DOI: $10.2478 /$ remav-2018-0023

\section{Introduction}

Recession is a business cycle contraction when an economy records two consecutive quarters of negative growth in real GDP. During this period, there is usually a decline in certain macroeconomic indicators, such as employment, investment spending, capacity utilization, household income and business income (CBN 2012; CRASHAW 2009; OYESIKU 2009). GDP, which refers to the Gross Domestic Product, is the value of all final goods and services produced within a given period of time. Mathematically, it can be represented as

$$
G D P=Y=C+I+G+N X
$$

where:

C - Consumption (The spending by households on goods and services, except purchases of new housing. 
I - Investment (the spending on capital equipment, inventories and structures, including new housing).

G - Government Purchases (the spending on goods and services by local, state and federal governments, but does not include transfer payments because they are not made in exchange for currently produced goods or services).

NX - Net Exports (Exports minus Imports) (Mankiw, n.d.).

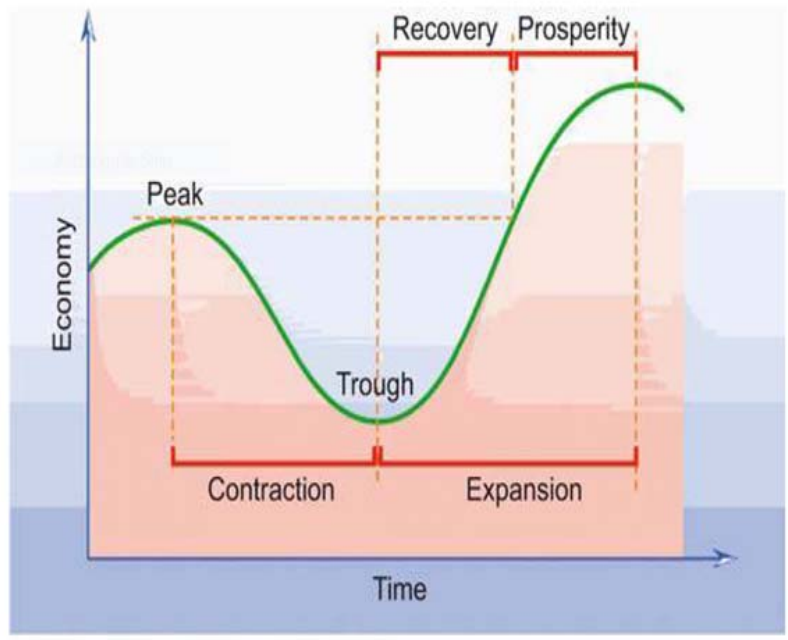

Source: Free software foundation

Fig 1. The Boom and Bust Cycle. Source: FRENCH (2011).

It is clear from the formula above that real estate plays an important role in the GDP of any economy and when a recession occurs, investment in this sector generally tends to be characterized by a high cost of building materials, long void periods, low occupancy rates and high vacancy rates (BELLO, BELLO 2007). In the case of Nigeria, the recession of 2015 came about as a result of both endogenous and exogenous factors, ranging from a fall in the global price of crude oil to poorly thought out fiscal policies seen by the apex bank of the country - the Central Bank of Nigeria (CBN), changing the fixed rate in the country to a floating one, leading to an escalation in foreign exchange rates (OLADAPO 2016). A multiplier effect of the recession saw investments in real estate bottom out considerably and rental values plummet due to reduced supply and high vacancy rates. This meant that properties which were let at a market rent (rack-rented) prior to the recession were now going for much less and, as such, had now become over-rented; hence, the need to capture the change in the property market by valuers became of even greater necessity. As posited by (Bello \& Bello, 2007), the current conventional investment method of valuation by Nigerian practitioners lacks merit and, with its emphasis on using the implicit nature of the All Risk Yield (ARY), is inappropriate in the valuation of freehold investment of a reversionary nature. This paper therefore takes a look at the conventional methods of erroneously valuing reversionary freehold properties in Nigeria by valuers with the initial and ARY, and throws more light on the equivalent yield with an explicit real value growth model as a more appropriate contemporary method of valuing properties in a downturn. Research questionnaires will be distributed to professional valuers and academics alike, posing them with a model valuation question of a property to be valued in a downturn. The results from respondents will be discussed and compared with the model answer. The paper will conclude with recommendations and policy implications of applying a more contemporary approach to reversionary properties.

\section{Literature review - conventional methods of valuing reversionary properties}

There are two main approaches to the market valuation of investment properties. The first is the conventional approach which applies a capitalization rate to the current income flow with no explicit assumptions made about future value changes with the exception that, when the lease comes to an end, the valuer assumes that the income will revert back to the open market value (the reversionary value or reversion). The yield used is the ARY and implicitly incorporates future rental growth and risk. The second approach is the DCF explicit approach, which estimates the present value of a future income at an appropriate rate (equivalent yield), taking into consideration assessment of growth 
return, risk and assumptions about future lease and other events (CROSBY, HENNEBERY 2016). To be able to fully understand the irrationality behind the current use of conventional methods in the valuation of reversionary properties by valuers in Nigeria, the concept of market rent and market value have to be spelt out first. The various types of yields will also need to be highlighted to demonstrate market conditions underpinning the workings of valuations at any particular point in time.

The International Valuation Standard Council (IVSC, 2017) defined both market and rent and value as follows:

Market rent is the estimated amount for which a property would be leased on the valuation date between a willing lessor a willing lessee on appropriate lease terms in an arm's length transaction after proper marketing and where the parties had each acted knowledgeably, prudently and without compulsion.

Market value is the estimated amount for which an asset or liability should be exchanged on the valuation date between a willing buyer in an arm's length transaction after proper marketing and where the parties had each acted knowledgeably, prudently and without compulsion.

From the above it is clear that, in determining the market value of any investment property, consideration has to be taken of like comparables at any given point in time. Lease terms and rents from comparables similar to the subject property make it easier to arrive at the value using an ARY because of the stability in the market and a substantial number of transactions. However, when the market is in a bust, adjustment of lease terms and yields is more heuristic and will involve using a yield that reflects the downturn in the market at that particular point in time (FRENCH 2013). With most of the early valuers in Nigeria educated in the UK, it is easy to understand the disillusionment of the present crop of valuers over the inadequacy of yields used in market valuation of investment properties. A mismatch between values presented by local market evidence and values arrived at using UK literature, especially the valuation table, meant that valuers in Nigeria had to tweak the yield to ensure that theoretically computed values are brought to par with actual market prices (IGBOKO 1992; LERAMO 1992). Hence, (OGUNBA et al. 2005) employed Nigerian valuers to compensate for investors' expectations of income growth during a recession by using yields that were reversionary in nature, as the use of an ARY or initial capitalization rate overvalues the term and undervalues the reversion.

FRENCH and PATRICK (2015), in their definition of yield, summarized it as a benchmark in percentage terms of the attractiveness of an investment. They highlighted a plethora of property yields, some of which are very popular with valuers in Nigeria, such as the Net Initial Yield and All Risk Yield used to value rack-rented properties, and others which are hardly used, like the equivalent yield used to value reversionary properties.

\subsection{Net Initial Yield and All Risk Yield}

With reference to a fully let (rack-rented) property using the market rent as net income, the net initial yield is simply the ratio of the initial net rent over the gross capital (price). It is the yield that the investor will accept initially, knowing all the risks and growth associated with that property. NIYs derived from several comparables can be analyzed to determine an appropriate capitalization rate for the valuation of a subject property. This appropriate capitalization rate is what we term the All Risk Yield (ARY) (FRENCH, PATRICK 2015).

\section{Example 1}

Value a fully let freehold interest with a net income of N20,000 per annum. Recently let rack-rented comparables just sold in the open market for N300,000.

Net Initial yield $\frac{\text { Net Income }}{\text { Capital Value }}=\frac{20,000}{300,000}=7 \%$ (NIY)

ARY $=7 \%$ (Derived from comparable evidence)

Implicit method of Valuation

Market Rent N20,000

YP in perp @ 7\% 14.29

Capital Value $\quad 286,000.00$ 
This is by far the most popular method of valuing rack-rented properties in Nigeria and the ARY used is meant to reflect a multitude of factors ranging from return of capital, management costs, and depreciation, to the cost of selling. In the absence of sufficient sales transactions, the use of the ARY lacks credibility, especially in a country like Nigeria, where records of sales are not readily available. This non-availability of records can also be attributed to the current downturn in the Nigerian property market characterized by a lack of transaction evidence. Hence, valuers are confined to subjectively selecting capitalization rates or using yields which do not interpret the current market conditions. The multiplier effect of this is wide variation in value estimates and discrepancies in the valuation reports of identical income-producing properties (FRENCH 2006; IFEDIORA 1993). The YP (Years Purchase) used in the solution above is termed the Capitalization factor, which allows for the systematic return of capital over the life of the investment. In the case of freehold interest with income for a fixed period in excess of 60 years, or in perpetuity, or if a property is let at rack-rent, with market evidence of capitalization rates like the example above and YP in perp (1/i) used to capitalize the rent passing. This in valuation terms is also known as level annuity (BAUM, MACKMIN, NUNNINGTON 2011).

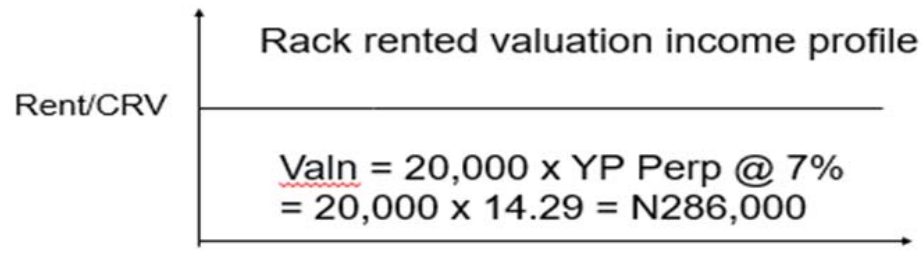

Fig 2. Rack-rented valuation income profile. Source: CROSBY (2016).

\subsection{Reversionary/equivalent yield}

BAUM, MACKMIN and NUNNINGTON (2011), in trying to distinguish between equated and reversionary yield, defined reversionary yield as a weighted average yield to be expected from an investment in terms of current rental value and without allowing for future growths in rental income. Also known as the IRR (Internal Rate of Return) of an investment, it is the appropriate yield used to value a reversionary property (whether over-rented or under-rented). The reversionary yield, on the other hand, is the ratio of the reversionary rent over the capital value of a reversionary property. The trial rates of both initial and reversionary yields assuming no future rental value growth are termed an equivalent yield. Reversionary properties first came into vogue in 1970-1990, when the UK property market first crashed. Prior to this, property was valued based solely on derivation of yields (NIY \& ARY) from the comparative analysis of transactions of similar properties. Inflation at that time (in the 1950s) was seen as a fluctuating phenomenon rather than a persistent one, and when bond yields rose due to post-war inflation in the late 1950s, property capitalization rates rose too. The UK property market had always been characterized by long occupational leases (21 years, $42-90$ years) with no rent reviews for prime assets. The property crash of 1970 brought about an introduction of rent freeze on commercial properties. This restricted a landlord to the receipt of existing rents only, even when the original lease allowed for increased rents. Investors realized that current income was more secure than the prospective increase at a rent review and the risk differential between the current income and the potential reversionary uplift was highlighted.

This led to the standardization of leases at 25 years with upward only rental reviews, which protected landlords from the rising costs of repair by transferring full responsibility for repairs and insurance on the tenant. Valuers distinguished between income derived from the existing rent and any prospective increase in rent at rent review or upon reversion (end of the lease). This gave birth to incomes being sliced horizontally rather than vertically. This technique reflected the changing perspectives of investors and valuers between agreed rents and the less certain level of those rents in the future by intuitively adjusting the yield between transactions from comparable properties and the subject property to highlight the perceived risks (CROSBY, HENNEBERY 2016). Nigeria was colonized by the United Kingdom and, as such, most of the early academics and practicing surveyors were trained in the UK and inherently adopted this method of valuation which erroneously believed that rent passing at the time of a lease or at the termination of a lease had more value than a lease with an 
unexpired term or one which was yet to be entered into. This meant that the term was capitalized at a lower yield than the reversion to highlight the perceived riskiness of income to be received some time in the future. Below are some of the conventional methods used by Nigerian valuers and academics in valuing freehold reversionary (both under rented and over-rented) properties during the 90s, and erroneously still widely used in practice today.

\section{Reversionary Valuation}

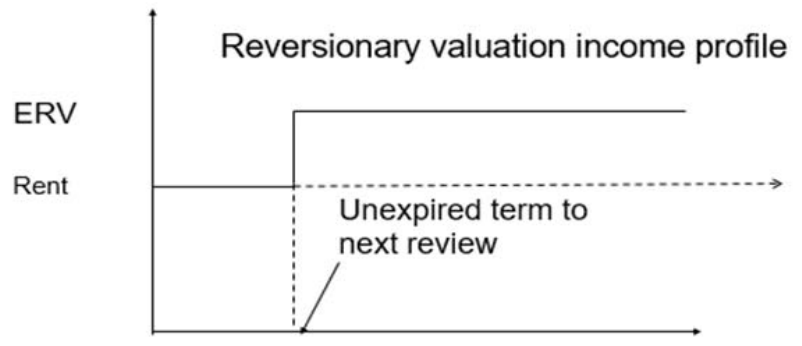

Fig 3. Reversionary valuation income profile. Source: CROSBY (2016).

\section{Example 2}

Value the freehold interest in an office building let on a 15-year lease, having 4 years to run and producing a net income of N250,000 per annum. The rental value is N600,000 per annum. The freehold capitalization rate based on market evidence of comparable properties is $7 \%$

\section{Using Term and Reversion Method (Under-rented)}

Term

Net Income (N) 250,000

YP 4yrs@6\% $\quad 3.465$

$866,250.00$

\begin{tabular}{|c|c|c|}
\hline Reversion & 600,000 & \\
\hline YP in perp @7\% & 15.71 & \\
\hline PV 4yrs@ @\% & 0.7629 & \\
\hline $\begin{array}{l}\mathrm{CV} \\
\text { Valuation }(=\mathrm{N}=)\end{array}$ & & $\begin{array}{l}7,191,095.00 \\
\mathbf{8 . 0 5 7 3 4 5 . 0 0}\end{array}$ \\
\hline
\end{tabular}

\section{Example 3}

Value the freehold interest in a property let on a 15-year lease, having 4 years to run and producing a net income of $\mathrm{N} 600,000$ per annum. The rental value is N250,000 per annum. The freehold capitalization rate based on market evidence of comparable properties is $7 \%$.

\section{Using the Layer Method (Over-rented)}

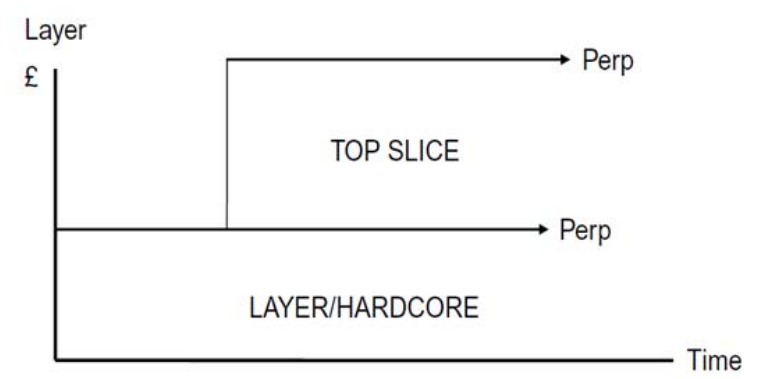

Fig 4. Layer Method Profile. Source: CROsBy (2016). 


\begin{tabular}{ll} 
(Bottom Slice) & \multicolumn{2}{l}{250,000} \\
YP perp @ 7\% & 14.29 \\
\cline { 2 - 2 } $3,572,500.00$
\end{tabular}

\begin{tabular}{lll} 
(Top Slice) (overage) & 350,000 & \\
YP 4yrs @ 9\% & 3.24 & \\
\cline { 2 - 2 } CV & $1,134,000.00$ \\
Valuation (=N=) & $\underline{\mathbf{4 , 7 0 6 , 5 0 0 . 0 0}}$
\end{tabular}

The rationale behind using the layer method was that, against the background of significant rental growth in the previous years, an investor buying a reversionary freehold interest would be purchasing a relatively safe income stream for a few years up to the next rent view. On review, there was perceived to be no chance of the rent falling below the current rent passing, and a very slim chance of it falling far enough below the estimated rental value to reach back down to the rent passing. Given a long lease, this completely secure bottom slice, extending well into the future, could be perceived to be less risky than the reversionary increase to rental value. This top slice part of the valuation suffers from risks in that the expected rental growth might not be realized and the estimate of current rental value might be incorrect. As it is a top slice income, any possible errors in these estimates will change the value of the top slice out of all proportion to those errors as it is a volatile cash flow (CROSBY 2016). It is pertinent to state here that the layer technique came about as result of the open-ended rent freeze policy imposed by the conservative UK government in 1971 (as a result of rising inflation due to lack of supply), which prevented landlords from charging higher rents and partaking in the growth of their properties. This introduced an unprecedented level of uncertainty in the property market and valuers had to naturally and innovatively start viewing the top slice (reversion) as a completely new flow of income on top of the continuation of the term income. The cash flow was split horizontally into a layer/hardcore and a top slice. The layer could be valued at an ARY that reflected the security of the continuing layer income, and then, the top slice could be valued at a much higher yield that reflected the uncertainty of the top slice not being achieved at a reversion but at a later date (FRENCH 2013). For an over-rented property, like the example above, the overage was assumed to be riskier than the core because it is totally dependent on the tenant's ability to continue paying substantially over the real rental value. With no growth potential, the top slice was valued as a terminable, risky, fixed income. A criticism of this method is that the Estimated Rental Value (ERV) is double-counted as the income flow is valued twice. The ARY of 7\% (growth implicit yield) used to capitalize the ERV shows that, even though the rent passing is higher than the ERV, the growth at each rent review eats into the overage. Although the overage actually diminishes during the lease term, the valuation assumes that it stays the same. Another criticism was that the overage might be eliminated before the end of the lease and, therefore, the valuation of the overage for 11 years might be too long. To remedy the flaws in the valuation of an over-rented property, especially in an economy like Nigeria, which is currently facing a recession (with few property transactions and declining property values), the need to use an appropriate yield that reflects the current state of the Nigerian property market and captures growth once the market has bottomed out has necessitated the need for adopting a more contemporary method of valuing properties in a downturn.

\section{Equated Yield}

The equated yield technique is a contemporary investment valuation technique postulated by Phillip Marshall in the mid-1970s which he termed "equated yield analysis" (MARSHALL 1976). The technique made use of an Internal Rate of Return (IRR) to distinguish between a redemption yield and an all risk yield (growth implicit capitalization rate) used in conventional property investment appraisals. The basis of the equated yield technique is that it increases the rent by rental growth before discounting at equated yield (UDO 2009). There are two main forms of the equated yield technique; these are:

(a) Equated Yield Technique by Formula: The main purpose of the equated yield technique by formula is to establish a summation model to create a multiplier for use with the current rental value to arrive at the capital value of the property. The capital value is the summation of the discounted value of each tranche of income. 
(b) YP of whole term=Ypt@e $+\left((1+g)^{t} \times \mathrm{Ypt} @ \mathrm{e} \times \frac{1}{(1+e)^{t}}\right)$

$$
\begin{aligned}
& =\mathrm{Ypt} @ \mathrm{e}+\left(1+\frac{(1+g)^{t}}{(1+e)^{t}}+\frac{(1+g)^{2 t}}{(1+e)^{2 t}}+\cdots\right) \\
& =\operatorname{YPt} @ e\left(\begin{array}{c}
\frac{(1+\mathrm{g})^{\mathrm{n}}}{(1+\mathrm{e})^{\mathrm{n}}} \\
\frac{1-(1+\mathrm{g})^{\mathrm{t}}}{(1+\mathrm{e})^{\mathrm{t}}}
\end{array}\right)
\end{aligned}
$$

where:

e - equated yield,

$\mathrm{t}$ - rent review interval,

$\mathrm{n}$ - total term of the property interest,

g - implied annual rental growth rate.

(c) Equated Yield Technique by Explicit DCF: The format of the equated yield technique by explicit DCF is such that the discounting process will reduce the value of future tranches of income (whether freehold or leasehold) to a nominal amount, by which point the cash flow projection may cease (Baum and Crosby, 1988, 118). It is an explicit cash flow model presented in a format that all growth potential of the investment is made obvious. In the appraisal of freehold property investment, the discounting process may be inconveniently lengthy and, to solve the dilemma, the shortened explicit cash flow model was proposed and recommended for use in the termination of cash flow projection at an envisaged resale point (UDO 2009). The assumption of a resale point in the investment market would coincide with a reversion or rent review, making it possible to terminate the cash flow projections, replacing future cash flows by the resale price. The resale price is arrived at by capitalization of the then rental values at a rate which implies future rental growth.

\section{Contemporary method of valuing properties using the equated yield and growth explicit method}

FRENCH (2013) outlined the following issues a valuer needs to address when valuing an over-rented property:

1) Deriving an appropriate equivalent yield (capitalization rate) from the analysis of other overrented comparables on the market, suitably adjusted to reflect the risks and benefits associated with the subject property. If no such comparables exist, the valuer should analyze similar reversionary properties and adjust the yield accordingly to reflect the over-rented nature of the subject property.

2) Determining the appropriate MR for the cash flow by reference to the lease of the subject property.

3) The valuer will need to assess at what time, if any, the Market Rent (MR) will have grown sufficiently for the rent review clause to be invoked, so that the rent will increase at a future rent review. It is possible for MRs not to grow and the over-renting to continue for the duration of the lease.

4) The valuation should also reflect the current market conditions. These current market conditions shall include risk free rate, rent review, risk premium, and the target rate (equated yield) of the investor.

One of the most important inputs in an income valuation process is the equated yield of such an investment. BAUM and CROSBY (2007) suggest that the equated yield should be a percentage in returns rewarding enough to compensate the investor for the loss of capital in the investment forgone, that is the return that would have been gotten if capital had been invested in conventional gilts plus a risk 
premium. BALL et al. (2012) explains this further enthusing that "a conventional gilt provides a riskless nominal rate of return, its gross redemption yield, which can be used as a building block to consider pricing in other asset markets. It is a measure of total return, derived from explicit analysis of expected cash flows, and can be considered as a reward for loss of illiquidity. Any other investment which involves risk must be expected to provide a higher return". He argues, however, that index-linked gilts, which are a relatively new form of investment, offer compensation for inflation and reflect changes in the real risk rate much more than the conventional gilts, as conventional gilts reflect only expected inflation. If held to redemption, it cannot be protected against unexpected inflation. This assertion tends to go in tandem with (BAUM, CROSBY 2007) who are of the belief that, because of this anomaly, indexed-linked government bonds are used more as a proxy for risk-free rates than conventional gilts, although there is a risk that nominal return is uncertain. Hence the target rate which is indexed-linked, bonds used as a proxy for risk-free conventional gilts, plus a risk premium can be represented mathematically as

where:

$$
R_{N}=R F_{R}+I_{E}+R P
$$

$R_{N} \quad$ - Gross redemption yield on conventional gilts.

$\mathrm{RF}_{\mathrm{R}} \quad$ - Risk Free Rate.

RP - Risk Premium

Hence Target Rate $\mathrm{TR}=\mathrm{RF}_{\mathrm{R}}+\mathrm{RP}$

In choosing a risk-free rate of return in Nigeria, we are faced with the dilemma of choosing between treasury bills and federal government bonds. Treasury bills are short-term securities issued by the Central Bank of Nigeria on behalf of the Federal Government of Nigeria at a discount for a tenor ranging from 91 to 364 days, such that the income received is the difference between the purchase price and the amount received at maturity or prior to the sale. Treasury bills have zerodefault risk, are task free, and the yield/income on investment can be automatically reinvested in a higher investment (CBN 2017). Federal Government bonds, on the other hand, are long-term debt securities issued by the debt management office on behalf of the government with assurance of paying a periodic interest alongside with the principal at maturity. They are considered risk-free and relatively safe. This, and the fact that the coupon payments are fixed, makes them vulnerable to rises in inflation. FG bond prices tend to fall as inflation rises, because the purchasing power erodes. Interest in FG bonds is paid semi-annually and is exempt from taxes (DMO 2017). At the time of writing this paper, maturity dates of bonds in Nigeria are either pegged at 4 years 3 months, 9 years 11 months or 20 years, and yield $15.9899 \%, 16.2430 \%$ and $16.2499 \%$ respectively. Pursuant to the Debt Management Office (Establishment) Act of 2003, the Federal Government in April of 2017 introduced new FG retail saving bonds, which have 2-year and 3-year maturity at $13.189 \%$ and $14.189 \%$ respectively. They are similar to the former FG bonds, but the only difference is that interest is paid quarterly (DMO 2017). To mimic index-linked bonds of the UK, which are paid semi-annually with long-term maturities, and whose coupon rates are adjusted using RPI as a proxy for inflation, the RFR adopted in this paper will be the 20-year bonds because of the long-lease term (15 years expired) of the subject property. The yield of the 20 -year FG retail bond is approximately $16 \%$, thus about $1.26 \%$ below the present inflation rate of the country, which currently stands at $17.26 \%$.

\section{Example 4:}

Value the freehold interest as of today of an office building in a prime area let on 15-year lease, having 4 years to run and producing a net income of N600,000 per annum with 2-year upwards only rent review. The current rental value is N250,000 per annum. A similar property was sold for N12,000,000 six months ago. Tenant covenant is strong even though the market is in a downturn and investor's target rate is $21 \%$ ( $16 \%$ risk free rate of FG 20 -year bonds plus $5 \%$ property risk premium)

\subsection{Equivalent yield analysis}

If a property is let at less than its rental value, yield analysis cannot be just:

- Initial yield $=600,000 / 12,000,000=0.05 \%$,

- Reversionary Yield $=£ 250,000 / 12,000,000=0.02 \%$

- Needs Equivalent yield or weighted average, so the valuation needs to be done backwards

- Unexpired term to next rent change $=4$ years 


\section{Valuation at Initial Yield}

Conventional EY valuation Vertically Sliced

\begin{tabular}{|c|c|c|}
\hline \multirow{2}{*}{$\begin{array}{l}\text { Rent passing }(\mathcal{E}) \\
\text { YP 4yrs @ 2\% }\end{array}$} & 600,000 & \multirow{2}{*}{$2,286,000.00$} \\
\hline & 3.81 & \\
\hline Market Rent $(£)$ & 250,000 & \\
\hline YP in perp @2\% & 50 & \\
\hline PV 4yrs @ 2\% & 0.9238 & \\
\hline $\mathrm{CV}$ & & $11,547,500.00$ \\
\hline Valuation $(£)$ & & $13,833,500.00$ \\
\hline Less Price & & $12,000,000.00$ \\
\hline NPV @ 2\% & & $1,833,500.00$ \\
\hline
\end{tabular}

\section{Valuation at Reversionary Yield}

$\begin{array}{lll}\text { Rent passing }(£) & 600,000 & \\ \text { YP 4yrs @ 5\% } & 3.5460 & 2,127,600.00 \\ & & \\ \text { Market Rent }(£) & 250,000 & \\ \text { YP in perp @5\% } & 20 & \\ \text { PV 4yrs @ 5\% } & 0.8227 & \\ \text { CV } & & 4,113,500.00 \\ \text { Valuation (£) } & & 6,241,100.00 \\ \text { Less Price } & & 12,000,000 \\ \text { NPV @ 5\% } & & \mathbf{- 5 , 7 5 8 , 9 0 0 . 0 0}\end{array}$

\subsubsection{Equivalent yield formula}

Solve EY $=\mathrm{LTR}+\left[\left(+\mathrm{NPV} /\left(+\mathrm{NPV}+-\mathrm{NPV}^{*}\right) *(\mathrm{HTR}-\mathrm{LTR})\right]\left({ }^{*}=\mathrm{IGNORE}\right.\right.$ THE SIGNS $)$

where:

LTR - Lower trial rate

HTR - Higher trial rate

EY - Equivalent yield

EY $-2 \%+[(1,833,500 /(1,833,500+5,758,900) *(5 \%-2 \%)$

$=2 \%+[0.2415 * 3 \%]$

$=2 \%+0.7245 \%$

$=2.7245 \%$

$=3 \%$

\subsection{Growth analysis}

The contemporary valuation would take cognizance of growth. This growth would be calculated using a target rate. The target rate would take into account the risk premium of the property plus the going risk-free rate in the economy. As was highlighted before, the adopted RFR would be $13 \%$. A property RP of $5 \%$ shall be assumed for the property considering the location of the property and tenant covenant strength. A target rate of $21 \%(16 \%+5 \%)$ would therefore be used throughout this valuation process to determine the growth. This target rate of $21 \%$, also known as the equated yield, will help to determine at what rate the capitalization rate of $3 \%$ should grow annually. Unlike the property market in the UK, which has statutory 5-years upward rent reviews, Nigeria has no statutory rent review but, on average, rents are reviewed upwards every 2 years and, for the purpose of this paper, shall be adopted in analyzing the growth. 


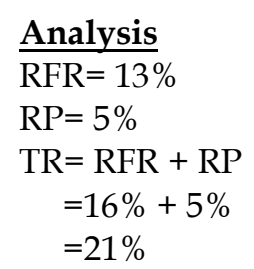

Implied Growth Rate Formular

$(1+\mathrm{g})^{\wedge} \mathrm{t}=\underline{\mathrm{YP} \text { Perp } @ \mathrm{k}-\mathrm{YP} \mathrm{t} \text { yrs } @ \mathrm{r}} \quad=$

YP Perp@ $3 \%$ - YP 2yrs @ 21\%

Where:

$$
\text { YP Perp@k } \times \text { YPt yrs@ }
$$

Rental Growth Rate $=$ g\% p.a

Review Pattern $=\mathrm{t}$ years

All Risk Yield $($ ARY $)=k \%$

Target Rate $=\mathrm{r} \%$
YP Perp@ $3 \% \times$ PV 2yrs @ 21\%

$31.79 / 22.74$

$(1+\mathrm{g})^{\wedge 2}=1.3980^{\wedge 0.5}$

$(1+\mathrm{g})=1.1824$

$\mathrm{g}=18 \%$

\subsubsection{Contemporary valuation using equated yield by formula}

$$
=\operatorname{YPt} @ e\left(\begin{array}{c}
\frac{(1+g)^{n}}{(1+e)^{n}} \\
\frac{1-(1+g)^{t}}{(1+e)^{t}}
\end{array}\right)
$$

Estimated Rental Value(ERV) $=\mathrm{N}=600,000$

Implied Rental Growth $(\mathrm{g})=18 \%$ p.a

Rent Review $(\mathrm{t})=2$ years

Total term $(n)=4$ years

YPperp = YP 2 years @ 21\% X

$$
\left(\begin{array}{c}
1-\frac{(1.18)^{4}}{(1.21)^{4}} \\
\frac{-\frac{(1.18)^{4}}{(1.15)^{4}}}{1} \\
1-\frac{1}{(1.18)^{4}} \\
\end{array}\right.
$$

YPperp $=1.5095 \times \frac{1}{0.0955}$

YPperp $=1.5095 \times 10.4712$

$=16$ (Approximately) 


\section{Solution}

$\begin{array}{lc}\text { Estimated Rental Value } & =\mathrm{N}=600,000 \\ \text { YP of whole term } & 16 \\ & 9,600,000\end{array}$

Valuation

$10,000,000$

4.2.2. Contemporary valuation using Equated yield by Explicit DCF

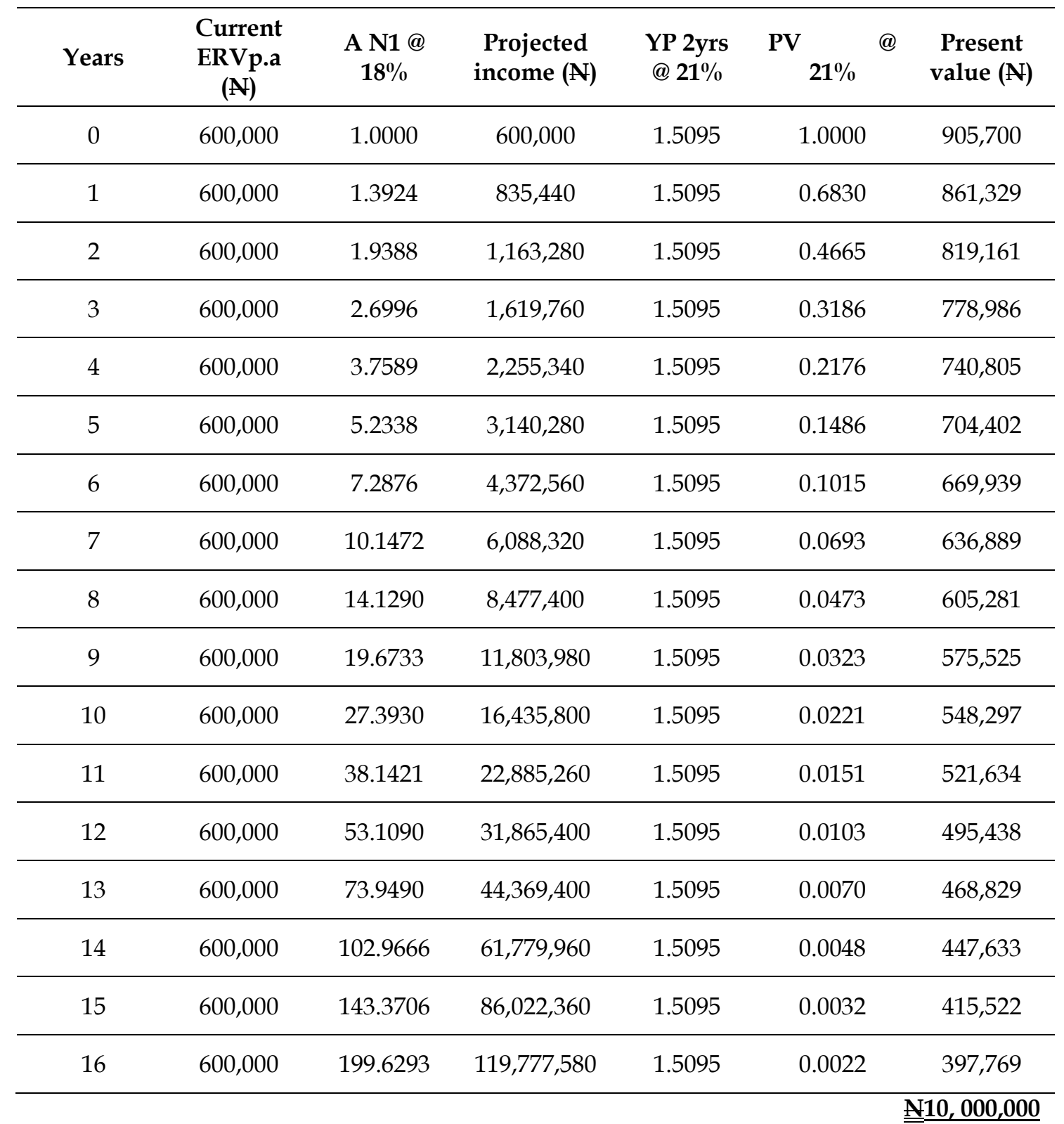

The basis of this model is that the current estimated rental value is increased by rental growth at each expected rent review period to a future projected rental income. The projected income is then discounted to present values at equated yield. The present value of the future tranches of income diminish in value as the holding period approaches the end and, at that point, future income flows are replaced by the resale price.

\section{Valuation of over-rented properties: pilot study}

In 2017, a short pilot study of valuers in Nigeria was carried out to determine how conversant valuers were with the use of the equivalent and explicit growth method of valuing reversionary properties in 
a downturn. The questionnaires were distributed to 20 practicing professional real estate surveyors and valuers (both in practice and academia), but only 10 were returned. The results can be viewed as indicative of the knowledge of the respondents as of the time of writing this research paper. The distributed questionnaire consisted of both open- and closed-ended questions which gave the respondents a chance to fully express themselves and participate adequately in the survey. The sample over-rented valuation solved in this paper was also included in the questionnaire for valuers to attempt to solve. The outcome of the survey suggests the following:

- All respondents are engaged in real estate valuation, but very few believed they had carried out valuations of over-rented properties in the last year.

- The valuers' knowledge of reversionary properties was limited to only freehold properties which were let out for a certain number of years and reverted back to the original owners. There was no reference to rental change.

- Initial yield was found to be the staple diet of valuers in practice, even when market rents in comparison to rents passing had fallen.

- Valuers faced a dearth of information when determining and adjusting for yields in carrying out their valuations.

- Most valuers still made use of the conventional hardcore and layer methods for valuing overrented properties without adequate provision for growth.

- Valuers were conversant with the equated yield method but were not knowledgeable enough to apply it in the valuation of over-rented properties.

- Although most of the respondents applied two-year rent review patterns to their valuations, there was a general consensus from the respondents that the federal government had a role to play in fixing standard rent review periods in accordance with the activities in the property market.

- A few of the respondents took cognizance of the happenings in the financial market when undertaking their valuations, while others based theirs on outgoings.

- Contemporary methods of investment valuations are taught in institutions of higher learning but are hardly applied in practice, hence the gap between knowledge and practice.

- Only one respondent attempted the sample valuation and came up with a valuation figure of $\mathrm{N}=\mathbf{1 0}, \mathbf{7 1 4}, \mathbf{2 8 5 . 0 0}$.

\section{Conclusions and recommendations}

This research has tried to bridge the knowledge gap that exists between valuers in Nigeria when it comes to valuing over-rented properties. The use of the traditional layer method of valuing reversionary over-rented properties is outdated as, these days, the risks are all perceived to be with the reversion (market rent) and its ability to grow and even surpass the rent passing at the next review if the unexpired term is long. The current recession facing the Nigerian economy today has caused a downturn in the property market which has made it even more difficult to determine ARY for valuations. Equivalent yield has been found to be the best yield for analyzing and valuing an overrented property, as it reconciles both initial and reversionary yields of an over-rented property using trial rates of (Net Present Values) NPVs, which mirror the true state of the market at any given point in time. There is need for the Nigerian Institution of Estate Surveyors and Valuers (NIESV) to carry out research to document yields and risk premiums of different property types at least twice a year, as this would go a long way in assisting valuers who, at the moment, are currently face a dearth of information when it comes to applying the appropriate yields when carrying out their valuations. The two-year rent review patterns currently used by valuers if adopted by the NIESV should be made statutory, as tenancy agreements have shown that yearly and three-year rent review patterns are also in vogue. It is recommended that the NIESV should take a cue from the RICS (Royal Institute of Chartered Surveyors) in the UK and, in conjunction with the federal government, come up with a standard rent review pattern which is made statutory and cuts across all investment properties so as to ensure some degree of uniformity amongst valuers when carrying out their valuations. Also, the education board of the NIESV has its work cut out for it if it is to improve the lot and skill set of valuers. Contemporary methods of valuation are already taught in tertiary institutions but should also be taught to valuers in practice through refresher courses as a means of updating their existing knowledge. Symposiums and lectures should be organized every now and then with experts from the financial sector to help keep valuers abreast of happenings in this sector. This is very important as the 
real estate sector cannot function effectively without the financial sector. Both sectors go in tandem, and a knowledge of the financial sector puts not just investors but also valuers in a better position to interpret the property market accurately. The NIESV, in conjunction with Real Estate funds in the country, should be able to research and publish, quarterly or yearly, the minimum threshold rate of return for equity investments (current risk premium that commercial property investors are willing to accept as an average minimum return above the RFR for equity investments. It is worthy to note that the equivalent yield and explicit growth method adopted here in valuing over-rented properties can also be used in the valuation of under-rented properties. Times are changing fast and the property market is more volatile than ever; thus the need to move from the norm and adapt our valuations to the current state of the market cannot be over-emphasized. Finally, it is pertinent to state here that the findings of this study are limited to the Nigerian market during a recessionary period and, although the contemporary equated yield and DCF explicit growth methods of valuation have been used in countries like the UK and Nigeria to achieve better results, the layer, term and reversion models are still very popular among valuers all over the world. It is yet to be seen if these contemporary methods of valuation are best suited for the over-rented property markets of other countries, hence the need for further research.

\section{References}

BAum A., CRosby N., 1988, Property Investment Appraisal, London: Routledge,

BAum A.E., CROSBy N., 2014, Property Investment Appraisal, 3; 3rd; edn, Wiley-Blackwell, Hoboken,

Baum A., Nunnington N., MACKMIN D., 2012, The Income Approach to Property Valuation, 1 st ed. Hoboken: Taylor and Francis,

BALl M., LiZIERI C., MACGREGor B., 1998, The Economics of Commercial Property Markets, illustrat;1; edn, Routledge Ltd, GB,

Bello M.O., Bello V.A., 2007, The Influence of Contemporary Models on Valuation Practice in Nigeria, Strategic Integration of Surveying Services, Hog Kong SAR, China 13-17 May 2007,

Central BanK OF Nigeria, 2012, Understanding Monetary Policy Series No 14: Economic Recession

CENTRAL BANK OF NiGERIA, 2017, www.cbn.gov.ng,

CRAWSHAW P., 2009, The Global Financial Crisis and Sub-Saharan Africa: The Efects of Slowing Private Capital Inflows on Growth, New York: South central,

Crosby N., 2016, Unpublished Lecture Series on Valuation Appraisal, Henley Business School, University of Reading.,

Crosby N., Henneberry J., 2015, Financialisation, The Valuation of Investment Property And The Urban Built Environment In The UK, Urban Studies 53.7:1424-1441,

DEBT MANAGEMENT OFFICE NigERIA, 2017, www.dmo.gov.ng/fgn-bonds,

FRENCH N, 2013, UK Freehold Reversionary Properties: Valuation Practice Revisited, Journal of European Real Estate Research 6.2:218-235,

French N., PATRICK M., 2015, The Plethora of Yields in Property Investment and Finance: a Summary, Journal of Property Investment \& Finance, 33(4), pp. 408-414,

FRENCH N., 2013, Reversionary Freehold Valuations: Over-rented Cash Flows by Spreadsheet, Journal of Property Investment \& Finance, 31(3), pp. 298-306,

IFEDIORA G.S.A., 1993, Appraisal Framework, 1st ed. Enugu, Nigeria: Iwuba Ifediora Associates,

IGвOKо N.P., 1992, Research Project on Valuation Methods in Nigeria with Special Reference to Years Purchase, Research report for the Nigerian Institution of Estate Surveyors and Valuers 1-43,

IVSC, 2017, International Valuation Standards, International Valuation Standard Council, London.

LERAMO G.A., 1992, The Groundwork of Property Valuation, Kaduna Polytechnic Press, Kaduna, 1, 1-3,

MANKIW N. (n.d.), Essentials of Economics, $1^{\text {st }}$ ed,

Ogunba O.A., AJAYI C.A., AluKO B.T., 2005, Substitution Vrsus Anticipation: a Resolution of the Nigerian Valuation Practice Paradox, Journal of Land Use and Development Studies, 1, (1), 1-10,

Oladapo F.A., 2016, Perspectives on the Nigerian Economic Recession, Centre for Allied Research and Economic Development, Policy Briefs PB023,

OYESIKU O., 2009, Global Economic Recession, the Environment and Sustainable Development in Nigeria, Urban journal, Vol. 2, pp. 40-46,

UdOeKANEM N.B., 2009, A Critical Examination of the Appropriate Application of Contemporary Valuation Techniques in the Determination of Market Values of Residential Property Investments in Uyo, Nigeria, 
M.Sc Dissertation, Department of Estate Management, University of Nigeria, Nsukka.

\section{Appendix}

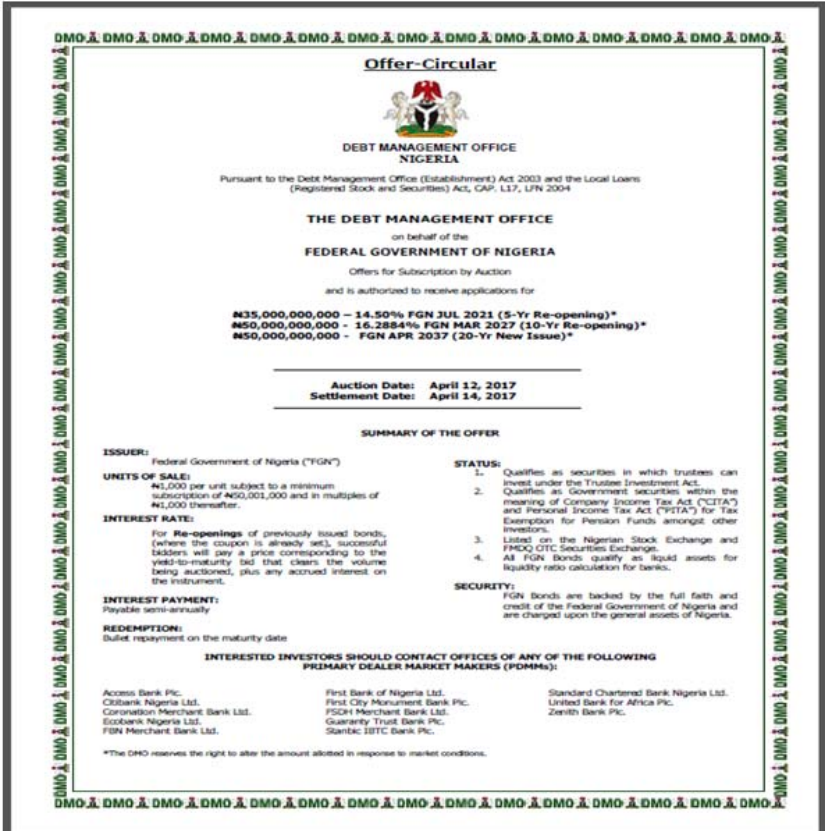

Nigeria Federal Government 5yr, 10yr \& 20yr bonds courtesy Debt Management Office, as of April, 2017

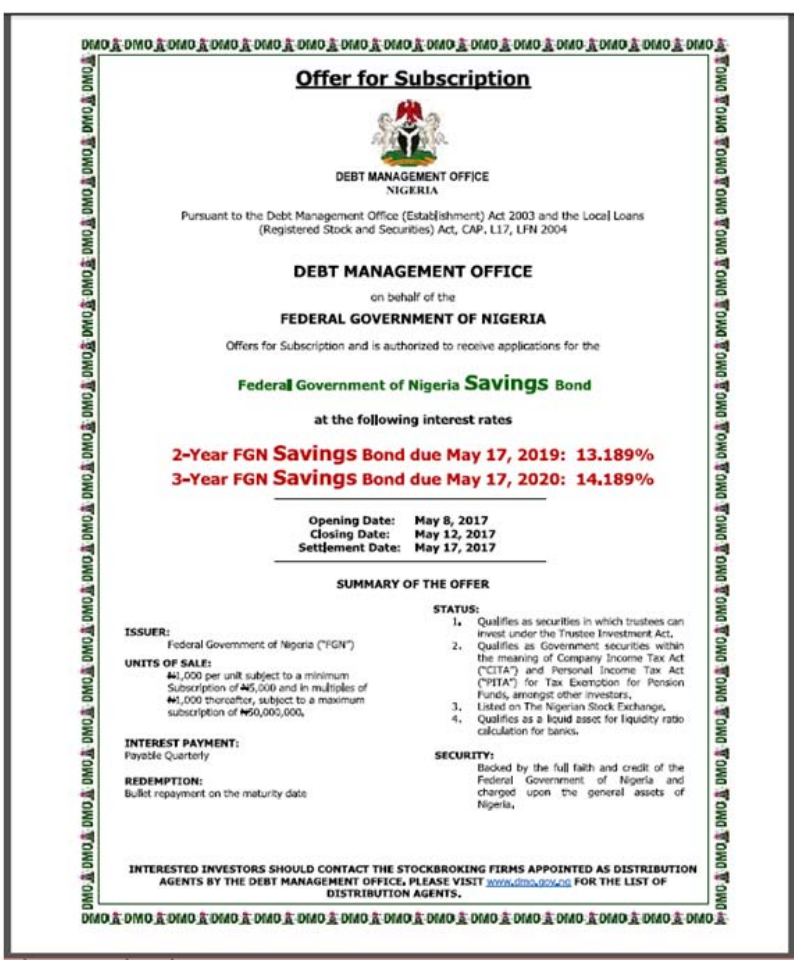

Nigeria Federal Government 5yr, 10yr \& 20yr bonds courtesy Debt Management Office, as of May 2017 


\section{The administered questionnaire}

Department of Estate Management Faculty of Environmental Science University of Benin Benin City, Edo State

12-05-2017.

Dear Respondent,

I am a lecturer in the above-named department currently engaged in a research titled:

"APPLICATION OF THE CONTEMPORARY EQUATED YIELD AND DCF EXPLICIT GROWTH METHODS IN THE VALUATION OF OVER-RENTED PROPERTIES IN A RECESSIONARY PERIOD: A CASE STUDY OF NIGERIA". It will be appreciated if you complete the attached questionnaire and solve the sample valuation question to help aid study. This is strictly an academic exercise and would not under any circumstance be used otherwise. Kindly be assured that your response or information supplied will be treated with utmost confidence. Please for ease of computing, please tick $[\checkmark$ ]where appropriate and answer adequately the open-ended questions on the questionnaire as presented to you in Microsoft Word format. The solution to the sample valuation question at the end can be attached to the completed questionnaire and a soft copy sent to uwaaihie@yahoo.com

Thanks for your anticipated co-operation.

AIHIE VINCENT UWAIFIOKUN (JNR)

\section{Questionnaire}

1. How long have you been in the Estate Surveying and Valuation profession?

(a) Below 5years [ ] (b)Between 5-10years [ ] (c) Above 10years [ ]

2. Do you engage in real estate valuation? (a) Yes [ ] (b) No [ ]

3. What do you understand by a reversionary property?.

4. In the last one year, how often have you carried out a valuation of an over-rented property? (a)Very Often [ ] (b)Often [] (c)Rarely [] (d)Never []

5. What methods do you employ in determining yields adopted for valuation of over-rented properties? Please specify....

6. Do you have sufficient evidence of All Risk Yields (equivalent yields) when carrying out valuations of over-rented properties in Nigeria? (a)Yes [ ] (b) No [ ]

7. Do you think you have sufficient evidence to adjust yields for your valuations? (a) Yes [ ] (b)No [ ]

8. What valuation methods do you adopt in valuing over rented properties? Please specify.....

9. What rent review pattern do you apply in your valuations? (a)1year review pattern [ ] (b) 2years review pattern [ ] (c) 3years review pattern [ ]

10. Do you take cognisance of happenings in the financial market when carrying out your valuations? (a)Very often [ ] (b) Often [ ] (c) Rarely [ ] (d) Never [ ]

11. Do you think the NIESV has a role to play in fixing standard rent review periods used in carrying out valuations? (a)Strongly agree [ ] (b)Agree [ ] (c) Strongly disagree [ ] (d)Disagree [ ] (e)Uncertain [ ] 12. How do you determine the risk premiums when carrying out your valuations? Please specify.............

13. Do you think you have sufficient evidence to determine risk premiums when valuing over-rented properties? (a) Yes [] (b)No []

14. Is there a need to review the current methods of valuing over-rented properties in Nigeria? (a) Strongly agree [ ] (b)Agree [ ] (c) Strongly disagree [ ] (d) Disagree [ ] (e) Uncertain

15. How often are contemporary methods of valuation taught in tertiary institutions offering Estate Management in Nigeria? (a)Very often [ ] (b) Often [ ] (c) Rarely [ ] (d) Never [ ]

16. Do you agree that graduates of Estate Management and Valuers in practice now more than ever need more training in carrying out Valuations using contemporary methods? (a) Strongly agree [ ] (b)Agree [ ] (c) Strongly disagree [ ] (d) Disagree [ ] (e) Uncertain

17. With your experience in valuation assignment, considering the scenario below, please execute the valuation of the freehold interest in an office building as of today in a prime area let on 15year lease 
having 4years to run and producing a net income of N600,000 per annum with 2year upwards only rent review pattern. The current rental value is N250,000 per annum. A similar property was sold for $\mathrm{N} 12,000,000$ six months ago. Tenant covenant is strong even though the market is in a downturn and investor's target rate is $21 \%$. Kindly make all necessary assumptions

Summary of survey questionnaire administered

\begin{tabular}{|l|l|l|l|l|l|l|}
\hline $\begin{array}{l}\text { Total no. of } \\
\text { respondents }\end{array}$ & $\begin{array}{l}\text { Number } \\
\text { involved } \\
\text { in } \\
\text { valuation }\end{array}$ & $\begin{array}{l}\text { Number } \\
\text { who } \\
\text { understood } \\
\text { what a } \\
\text { reversionary } \\
\text { property } \\
\text { meant and } \\
\text { had recently } \\
\text { carried out a } \\
\text { reversionary } \\
\text { valuation }\end{array}$ & $\begin{array}{l}\text { Number } \\
\text { who did } \\
\text { not have } \\
\text { sufficient } \\
\text { evidence } \\
\text { to adjust } \\
\text { yields for } \\
\text { valuation }\end{array}$ & $\begin{array}{l}\text { Number who } \\
\text { used the } \\
\text { Direct } \\
\text { Capitalization } \\
\text { method for } \\
\text { valuing } \\
\text { reversionary } \\
\text { properties }\end{array}$ & $\begin{array}{l}\text { Number } \\
\text { who } \\
\text { strongly } \\
\text { agreed" } \\
\text { there was } \\
\text { a need to } \\
\text { review the } \\
\text { current } \\
\text { method of } \\
\text { valuing } \\
\text { over- } \\
\text { rented } \\
\text { properties }\end{array}$ & $\begin{array}{l}\text { Number who } \\
\text { "strongly } \\
\text { agreed" that } \\
\text { valuers } \\
\text { needed more } \\
\text { training using } \\
\text { contemporary } \\
\text { methods }\end{array}$ \\
\hline $10 / 20$ & 10 & 5 & 8 & 10 & 8 & 7 \\
\hline
\end{tabular}

